\title{
ANALISIS RASIO PROFITABILITAS DAN RASIO LIKUIDITAS UNTUK MENILAI KINERJA KEUANGAN PADA PT. ASTRA INTERNASIONAL,TBK
}

\author{
Nina Shabrina ${ }^{1)}$ \\ 1) dosen universitas pamulang, email : nina.shabrina85@gmail.com
}

\section{ARTICLES INFORMATION}

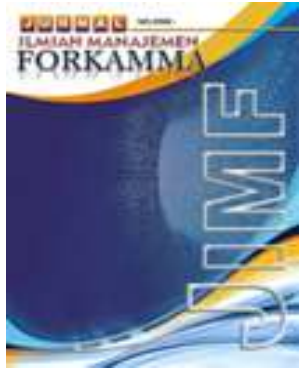

JURNAL ILMIAH MANAJEMEN FORKAMMA

\author{
Vol.2, No.3, Juli 2019 \\ Halaman : $62-75$ \\ (c) LPPM \& FORKAMMA
}

Prodi Magister Manajemen

UNVERSITAS PAMULANG

ISSN (online) : :2599-171X

ISSN (print) : :2598-9545

Keyword:

Profitabilitas dan Likuiditas

JEL. classification :

C33, G20, G23, N65

\section{Contact Author : \\ PRODI \\ MAGISTER MANAJEMEN \& FORKAMMA UNPAM \\ JL.Surya Kencana No.1 Pamulang \\ Tangerang Selatan - Banten \\ Telp. (021) 7412566, Fax (021) 7412491 Email : \\ jurnalforkamma.unpam@gmail.com}

Tujuan perhitungan rasio keuangan sangat dibutuhkan bagi suatu perusahaan agar dapat mengetahui kondisi keuangan baik buruk didalam pengolahan suatu perusahaan. Yang bertujuan untuk mengetahui Rasio Profitabiltas, Rasio Likuiditas dan Kinerja Keuangan yang mengunakan Rasio Profitabilitas dan Rasio Likuiditas pada PT.Astra International, Tbk. Metode yang digunakan dalam penelitian ini adalah metode Deskriptif Kuantitatif

Berdasarkan hasil penelitian ini yang mengunakan hasil pengukuran dengan alat ukur Rasio Profitabilitas dan Rasio Likuiditas pada PT.Astra International.Tbk, Pada tahun 2012 sampai dengan tahun 2016 pada Rasio Profitabilitas : Gross Profit Margin (GPM) mengalami kenaikan dan penurunan,yaitu $15 \%, 14 \% 13 \%, 10 \%$ dan 12\%. Maka Gross Profit Margin (GPM) dari tahun 2012 sampai dengan 2016 masih dikatakan kurang sehat bila dilihat dari standar industri itu sendiri yang sebesar 30\%.sedangkan Return on Equity (ROE) 25\% $, 21 \%, 18 \%, 13 \%$ dan $14 \%$. Return on Equity (ROE) dari tahun 2012 sampai dengan 2016 masih dikatakan kurang sehat bila dilihat dari standar industri itu sendiri yang sebesar 40\%.Pada tahun 2012 sampai dengan 2016 pada Rasio Likuiditas : Current Ratio (CR) mengalami kenaikan dan penurunan $140 \%$, $120 \%, 140 \%$, $140 \%$, 120\%, maka Current Ratio (CR) dinyatakan kurang sehat dilihat dari standar industri itu sendiri yang sebesar 200\%. Sedangkan pada Quick Ratio (QR) mengalami kenaikan dan penurunan, $110 \%, 103 \%, 109 \%$, $113 \%$ dan $104 \%$, maka Quick Ratio (QR) dinyatakan kurang sehat dilihat dari standar industri itu sendiri yang sebesar $150 \%$. Kinerja Keuangan pada PT.Astra International.Tbk memperoleh rata-rata nilai dari Profitabilitas dengan menggunakan Gross Profit Margin (GPM) yang dihasilkan selama 5 (lima) tahun menunjukan angka 12,8\% dan dengan menggunakan Return on Equity (ROE) selama 5 (lima) tahun menunjukan angka 18,2\%. Hal ini menunjukan Kinerja Keuangan perusahaan dari segi Profitabilitas dinyatakan kurang sehat. Kemudian dari segi Likuiditas dengan menggunakan Current Ratio (CR) selama 5 (lima) tahun menunjukan angka $130 \%$ dan dengan menggunakan Quick Ratio (QR) selama 5 (lima) tahun menunjukan angka 107,8\%. $\mathrm{Hal}$ ini menunjukan Kinerja Keuangan perusahaan dari segi Likuiditas dinyatakan kurang sehat. 


\section{A. Pendahuluan}

Melihat perekonomian yang semakin berkembangan seringan dengan perkembangan di dunia usaha yang amat cepat. yang banyak bermunculan yang ditandai dengan semakin meningkatnya suatu persaingan usaha yang kompetitif. Menghadapi persaingan tersebut, perusahaan atau pimpinan perusahaan dituntut untuk mampu untuk mengelola faktor - faktor produksi yang ada secara efektif agar suatu perusahaan mencapai tujuan. Dalam hal ini pula perusahaan juga dituntut untuk mampu menentukan kinerja usaha yang baik. Sehingga perusahaan dapat memenuhi kebutuhan eksternal dan internal agar dapat menjamin kelangsungan hidup.

Secara umum perusahaan (business) adalah suatu organisasi dimana sumber daya (input), seperti bahan baku dan tenaga kerja diproses untuk menghasilkan barang atau jasa (output) bagi pelanggan. Tujuan dari perusahaan adalah untuk memaksimalkan laba atau keuntungan.

Menurut Brigham dan Houston (2010:84) "laporan keuangan adalah bebeapa lembar kertas dengan angka-angka yang tertulis diatasnya, tetapi penting juga untuk memikirkan asset-aset nyata yang berada dibalik angka tersebut".

Analisis rasio keuangan merupakan metode analisis yang paling sering digunakan karena merupakan metode yang paling cepat untuk mengetahui kinerja keuangan perusahaan. Dengan mengetahui kinerjanya, perusahaan dapat mengambil keputusan bisnis yang tepat guna mencapai tujuannya. Analisis laporan keuangan pada dasarnya merupakan perhitungan rasio-rasio untuk menilai keadaan keuangan di masa lalu, saat ini, dan kemungkinan di masa depan. Perusahaan didirikan dalam jangka waktu yang panjang untuk meningkatkan laba, maka dari itu harus mampum mempertinggi rasio laba. Jadi, perusahaan harus diarahkan ke titik profitabilitas yang maksimal sehingga tingkat kinerja perusahaan akan membaik dan perusahaan mengetahui tingkat Rasio Likuiditas maka perusahaan tersebut mampu dalam memenuhi kewajiban jangka pendek, tingkat likuiditas sangat berguna bagi perusahaan khususnya kreditur yang memberikan kredit jangka pendek. Salah satu cara untuk menilai efisiensi kinerja keuangan dari suatu usaha dalam manajemen keuangan adalah dengan menggunakan analisis rasio profitabilitas dan rasio likuiditas.

Rasio menggambarkan suatu hubungan atau pertimbangan antara suatu tertentu dengan jumlah yang lain dan dengan menggunakan alat analisa berupa analisa rasio. Analisa rasio ini akan dapat menjelaskan atau menggambarkan kepada analisa tentang baik atau buruknya, sehat dan kurang sehat keadaan atau posisi keuangan suatu perusahaan apabila angka rasio itu dibandingkan dengan angka rasio pembanding yang digunakan sebagai standar.

Berikut ini adalah data Rasio Profitabilitas dan Rasio Likuiditas yang dimiliki oleh PT. Astra International Tbk. pada tahun 2012-2016.

Tabel 1.1

Unsur Data Profitabilitas PT. Astra Internasional Tbk

\begin{tabular}{|c|c|c|c|c|}
\hline \multirow{2}{*}{ TAHUN } & \multicolumn{2}{|c|}{ GPM } & \multicolumn{2}{c|}{ ROE } \\
\cline { 2 - 5 } & LABA KOTOR & PENJUALAN & LABA BERSIH & MODAL \\
\hline 2012 & 27.898 & 188.053 & 22.742 & 89.814 \\
\hline 2013 & 27.523 & 193.880 & 22,297 & 106.188 \\
\hline
\end{tabular}




\begin{tabular}{|l|l|l|l|l|}
\hline 2014 & 27.352 & 201.701 & 22.125 & 120.324 \\
\hline 2015 & 19.630 & 184.196 & 15.613 & 126.533 \\
\hline 2016 & 22.253 & 181.084 & 18.302 & 139.906 \\
\hline
\end{tabular}

Sumber : Data diolah

Dilihat dari tabel di atas bahwa Laba Kotor pada tahun 2012 sebesar 27.898, mengalami penurunan pada tahun 2013 sebesar 27.523, mengalami penurunan pada tahun 2014 sebesar 27.352, mengalami penurunan pada tahun 2015 sebesar 19.630, dan pada tahun 2016 mengalami kenaikan sebesar 22.253. Penjualan pada tahun 2012 sebesar 188.053, mengalami kenaikan pada tahun 2013 sebesar 193.880, mengalami kenaiakan pada tahun 2014 sebesar 201.701, mengalami penurunan pada tahun 2015 sebesar 184.196, dan mengalami penurunan pada tahun 2016 sebesar 181.084. Laba bersih pada tahun 2012 sebesar 22.742, mengalami kenaikan pada tahun 2013 sebesar 22.297, mengalami penurunan pada tahun 2014 sebesar 22.125, mengalami penurunan pada tahun 2015 sebesar 15.613, dan pada tahun 2016 mengalami kenaikan pada tahun 18.302. Modal Sendiri pada tahun 2012 sebesar 89.814, mengalami kenaikan pada tahun 2013 sebesar 106.188, mengalami kenaikan pada tahun 2014 sebesar 120.324, mengalami kenaikan pada tahun 2015 sebesar 126.533, dan pada tahun 2016 mengalami penurunan sebesar 139.906 .

Tabel 1.2

Unsur Data Likuiditas PT. Astra International Tbk

\begin{tabular}{|c|c|c|c|c|c|}
\hline \multirow{2}{*}{ TAHUN } & \multicolumn{2}{|c|}{ CR } & \multicolumn{3}{c|}{ QR } \\
\cline { 2 - 6 } & $\begin{array}{c}\text { AKTIVA } \\
\text { LANCAR }\end{array}$ & $\begin{array}{c}\text { KEWAJIBAN } \\
\text { LANCAR }\end{array}$ & $\begin{array}{c}\text { AKTIVA } \\
\text { LANCAR }\end{array}$ & $\begin{array}{c}\text { KEWAJIBAN } \\
\text { LANCAR }\end{array}$ & PERSEDIAAN \\
\hline 2012 & 75.799 & 54.178 & 75.799 & 54.178 & 15.285 \\
\hline 2013 & 88.352 & 71.139 & 88.352 & 71.139 & 14.433 \\
\hline 2014 & 97.241 & 73.523 & 97.241 & 73.523 & 16.986 \\
\hline 2015 & 105.161 & 76.242 & 105.161 & 76.242 & 18.337 \\
\hline 2016 & 110.403 & 89.079 & 110.403 & 89.079 & 17.771 \\
\hline
\end{tabular}

Sumber : Data diolah

Dilihat dari data diatas maka Aktiva Lancar pada tahun 2012 sebesar 75.799, mengalami kenaikan pada tahun 2013 sebesar 88.452, mengalami kenaikan pada tahun 2014 sebesar 97.241, mengalami kenaikan pada tahun 2015 sebesar 105.161, dan pada tahun 2016 mengalami kenaikan sebesar 110.403, Hutang Lancar pada tahun 2012 sebesar 54.178, mengalami kenaikan pada tahun 2013 sebesar 71.139, mengalami kenaikan pada tahun 2014 sebesar 73.523, mengalami kenaikan pada tahun 2015 sebesar 76.242, dan pada tahun 2016 mengalami kenaikan sebesar 89.079. Persediaan pada tahun 2012 sebesar 15.285, mengalami kenaikan pada tahun 2013 sebesar 14.433, mengalami kenaikan pada tahun 2014 sebesar 16.986, mengalami kenaikan pada tahun 2015 sebesar 18.337, dan pada tahun 2016 mengalami penurunan sebesar 17.771 .

Berdasarkan data di atas, maka peneliti tertarik untuk membuat penelitian yang berjudul "Analisis Rasio Profitabilitas dan Rasio Likuiditas Untuk Menilai Kinerja Keuangan Pada PT. Astra International Tbk". 


\section{a) Perumusan Masalah}

Berdasarkan identifikasi masalah di atas penulis merumuskan masalah sebagai berikut:

1. Bagaimana rasio Profitabilitas PT. Astra International Tbk pada tahun 2012-2016 ?

2. Bagaimana rasio Likuiditas PT. Astra International Tbk pada tahun 2012-2016 ?

3. Bagaimana kinerja keuangan PT. Astra International Tbk diukur dengan rasio profitabilitas dan Rasio Likuiditas pada tahun 2012-2016?

\section{b) Landasan Teori}

\section{Rasio Profitabilitas}

Analisis profitabilitas memfokuskan terutama pada hubungan hasil usaha dalam laporan laba rugi dan sumber daya perusahaan yang tersedia sebagaimana dilaporkan dalam laporan posisi keuangan (Neraca). Angka rasio mengukur kemampuan perusahaan menghasilkan laba. Kemampuan menghasilakan laba sangat tergantung kepada efektifitas dan efesiensi dari usaha dan sumber daya perusahaan yang tersedia.

Menurut Firdaus A. Dunia (2013:383) "Profitabilitas adalah Analisis rasio untuk mengukur kemampuan perusahaan dalam menghasilkan laba".

Menurut Brigham dan Houston (2010:146) "Profitabilitas adalah Rasio yang menunjukan kombinasi dari pengaruh likuiditas, manajemen aset, dan utang pada operasi".

\section{Jenis Rasio Profitabilitas}

a. Gross Profit Margin (GPM

Menurut Brigham dan Houston (2010:146) "Gross Profit Margin Merupakan mengukur laba kotor perdolar dengan penjualan dihitung dengan membagi laba kotor dengan penjualan".

Menurut Firdaus A. Dunia (2013:384) "Profit Margin adalah ukuran profitabilitas yang mengukur berapa laba yang diperoleh untuk setiap rupiah penjualan hasilnya".

Menurut Agnes Sawir (2009:18) "Gross Profit Margin merupakan rasio yang mengukur efisiensi pengendalian harga pokok atau biaya produksinya mengidentifikasi kemampuan perusahaan untuk memproduksi secara efisien".

Rumus untuk mencari Gross Profit Margin sebagai berikut :

$$
\text { Gross Profit Margin }=\frac{\text { Laba Kotor }}{\text { Penjualan Bersih }} \times 100 \%
$$

\section{b. Net Profit Margin (NPM)}

Net Profit Margin merupakan rasio yang digunakan untuk menunjukan kemampuan perusahaan dalam menghasilkan keuntungan bersih. Menurut Lukman Syamsudin (2007:62) "Net profit Margin adalah rasio antar laba bersih (Net profit) yaitu penjualan sesudah dikurangi dengan seluruh expenses termaksuk pajak dibandingkan dengan penjualan". Semakin tinggi Net Profit Margin, semakin baik operasi suatu perusahaan.

Rumus untuk mencari Net Profit Margin sebagai berikut :

$$
\text { NPM }=\frac{\text { Laba Bersih Setelah Pajak }}{\text { Penjualan Bersih }} \times \mathbf{1 0 0 \%}
$$

c. Return on Investment (ROI)

Return on investment merupakan perbandingan antara laba bersih setelah pajak dengan total aktiva. Menurut Irham Fahmi (2011:137) "Rasio ini melihat sejauh mana 
investasi yang telah ditanamkan mampu atau dapat memberikan pengembalian keuntungan sesuai dengan yang diharapkan".

Rumus untuk mencari Return On Investment sebagai berikut :

$$
\text { ROI }=\frac{\text { Laba Bersih Setelah Pajak }}{\text { Total Aktiva }} \times \mathbf{1 0 0 \%}
$$

\section{d. Return on Equity (ROE)}

Return on Equity merupakan perbandingan antara laba bersih setelah pajak dengan total equity. Menurut Agnes Sawir (2009:20) Return on Equity "Merupakan rasio yang memperlihatkan sejauh manakah perusahaan mengelolah modal sendiri secara efektif,mengukur tingkat keuntungan dari investasi yang telah dilakukan pemilik modal sendiri atau pemegang saham perusahaan". Return on Equity merupakan suatu pengukuran dari penghasilan (income) yang tersedia bagi para opemilik perusahaan (baik pemegang saham biasa maupun pemegang saham preferen) atas modal yang mereka investasikan didalam perusahaan.

Rumus untuk mencari Return On Equity sebagai berikut :

$$
\text { ROE }=\frac{\text { Laba Bersih Setelah Pajak }}{\text { Ekuitas }} \times 100 \%
$$

\section{Rasio Likuiditas}

Likuiditas adalah berhubungan dengan masalah kemampuan suatu perusahaan untuk memenuhi kewajiban finansialnya yang segera harus dipenuhi jumlah alat-alat pembayaran (alat likuid) yang dimiliki oleh suatu perusahaan pada suatu saat merupakan kekuatan membayar dari perusahaan yang bersangkutan. Suatu perusahaan yang mempunyai kekuatan membayar belum tentu dapat memenuhi segala kewajiban finansialnya yang segera harus di penuhi atau dengan kata lain perusahaan tersebut belum tentu memiliki kemampuan membayar.

\section{Jenis Rasio Likuiditas}

a. Rasio Lancar (Current Ratio)

Rasio Lancar (Current Ratio) biasanya digunakan sebagai alat untuk mengukur keadaan likuiditas suatu perusahaan dan juga merupakan petunjuk untuk dapat mengetahui dan menduga sampai dimanakah perusahaan tersebut memberikan kredit berjangka pendek dapat memberikan rasa aman. Current ratio merupakan suatu indikator likuiditas yang lebih andal dibandingkan modal kerja.

Menurut Firdaus A. Dunia (2013:383) "Current Ratio adalah ukuran likuiditas yang merupakan selisih antara aset lancar dan liabilitas (kewajiban) jangka pendek".

Menurut Brigham dan Houston (2010:134) "Rasio lancar merupakan rasio yang dihitung dengan membagi aset lancar dengan kewajiban lancar".

\section{b. Rasio Cepat (Quick Ratio)}

Rasio Cepat (Quick Ratio) rasio ini disebut juga sebagai acid test ratio yaitu perbandingan antara aktiva lancar dikurangi persediaan dengan utang lancar rasio ini merupakan ukuran kemampuan perusahaan dalam memenuhi kewajibannya dengan tidak memperhitungkan persediaan. Quick ratio merupakan rasio antar jumlah aset lancar di luar persediaan dan biaya dibayar dimuka dengan liabilitas jangka pendek.

Menurut Brigham dan Houston (2010:135) "Rasio cepat merupakan rasio yang dihitung dengan mengurangi persediaan dengan aset lancar". 
Menurut Firdaus A. Dunia (2013:383) "Quick Ratio adalah ukuran likuiditas yang merupakan perbandingan antara aset yang cepat dijadikan uang (kas,surat-surat berharga) dan liabilitas jangka pendek".

Rumus untuk mencari Rasio Cepat atau Quick Ratio sebagai berikut :

$$
\text { Quick Ratio }=\frac{\text { Aktiva Lancar }- \text { Persediaan }}{\text { Kewajiban Lancar }} \times 100 \%
$$

\section{Kinerja Keuangan}

Kinerja keuangan adalah suatu analisis yang dilakukan untuk melihat sejauh mana suatu perusahaan telah melaksanakan dengan menggunakan aturan-aturan pelaksanakan keuangan secara baik dan benar.

Menurut Mulyadi (2010:415) "Penilaian kinerja adalah penentuan secara periodik efektivitas operasional secara organisasi, bagian organisasi dan karyawannya berdasarkan sasaran, standar, dan kriteria yang telah ditetapkan sebelumnya". Karena organisasi pada dasarnya dijalankan oleh manusia maka penilian kinerja sesungguhnya merupakan penilaian atas perilaku manusia dengan melaksanakan perannya dalam suatu organisasi.

\section{c) Metodologi Penelitian}

Metode yang digunakan dalam pengumpulan data yang berkenaan pada penulisan skripsi ini menggunakan dua teknik metode pengumpulan data yaitu sebagai berikut:

\section{Sumber Data}

Sumber data dalam penelitian ini adalah sumber dari mana data ini diperoleh. Sumber data dibagi menjadi 2 yaitu:

a. Data primer

Data primer adalah data yang diperoleh atau dikumpulkan langsung dilapangan oleh orang yang melakukan penelitian atau bagi yang bersangkutan memerlukannya.

b. Data sekunder

Data sekunder adalah pengumpulan data melalui riset perpustakaan, untuk memperoleh data yang teoritis dan ilmiah yang dapat digunakan sebagai landasan dalam menganalisa permasalahan.

Maka dapat di simpulkan bahwa dalam penelitian ini mengunakan data sekunder berupa dokumen perusahaan yang akan diteliti dengan menggunakan berbagai sumber kepustakaan. Sumber data yang digunakan dalam penilitian ini adalah sumber data sekunder yang diperoleh dari Bursa Efek Indonesia (BEI) atau PT. Indonesia Capital Market Electronic Library. Data sekunder yang digunakan adalah laporan keuangan berupa neraca dan laporan rugi laba tahun 2012 sampai dengan tahun 2016.

\section{Teknik Pengumpulan Data}

Dalam penelitian ini metode analisis data yang digunakan adalah metode analisis kuantitatif dengan pendekatan deskriptif dimana metode ini merupakan metode yang digunakan penulis untuk mengumpulkan data-data kuantitatif, yaitu data-data dalam bentuk angka atau bilangan yang diinterprestasikan kedalam suatu tabel, kemudian penulis menafsirkan data tersebut sehingga dapat memberikan gambaran yang nyata mengenai keadaan perusahaan.

Dalam praktiknya penggunaan metode ini adalah dengan menggunakan analisis rasio keuangan yaitu dengan menggunakan analisis Rasio Likuiditas dan analisis Rasio Profitabilitas. Dimana rasio likuiditas bertujuan unutk mengetahui kemampuan 
perusahaan dalam memenuhi kewajiban jangka pendeknya dengan aktiva lancarnya. Sedangkan rasio profitabilitas yaitu rasio untuk mengukur kemampuan perusahaan dalam memperoleh laba atau keuntungan pada periode tertentu.

\section{Hasil Penelitian}

Perhitungan kinerja keuangan ini menggunakan 2 (dua) alat rasio keuangan yaitu Rasio Profitabilitas dan Rasio Likuiditas untuk menilai kinerja keuangan pada PT. Astra International Tbk :

\section{Rasio Profitabilitas}

Rasio Profitabilitas adalah untuk memfokuskan terutama pada hubungan hasil usaha dalam laporan laba rugi dan sumber daya perusahaan yang tersedia sebagaimana dilaporkan dalam laporan posisi keuangan (Neraca). Angka rasio mengukur kemampuan perusahaan menghasilkan laba. Kemampuan menghasilakan laba sangat tergantung kepada efektifitas dan efesiensi dari usaha dan sumber daya perusahaan yang tersedia.

a. Gross Profit Margin (GPM)

Gross Profit Margin merupakan rasio yang mengukur efisiensi pengendalian harga pokok atau biaya produksinya mengidentifikasi kemampuan perusahaan untuk memproduksi secara efisien. Dengan mengukur laba kotor dengan penjualan dihitung dengan membagi laba kotor dengan penjualan.
Gross Profit Margin pada tahun $2012=\frac{27.898}{188.053} \times 100 \%=15 \%$
Gross Profit Margin pada tahun $2013=\frac{27.523}{193.980} \times 100 \%=14 \%$
Gross Profit Margin pada tahun $2014=\frac{\frac{1735}{201701}}{20100} \times 13 \%$
Gross Profit Margin pada tahun $2015=\frac{191630}{184.196} \times 100 \%=10 \%$
Gross Profit Margin pada tahun $2016=\frac{22.253}{181.084} \times 100 \%=12 \%$

Tabel 4.1
Laporan Laba Kotor dan Penjualan PT. Astra International.Tbk
Periode (2012-2016)
(Dalam Miliaran Rupiah)

\begin{tabular}{|c|c|c|c|c|l|}
\hline \multirow{2}{*}{ Tahun } & \multicolumn{2}{|c|}{ GPM } & \multirow{2}{*}{$\begin{array}{c}\text { Hasil } \\
\text { GPM }\end{array}$} & $\begin{array}{c}\text { Standar } \\
\text { Industri }\end{array}$ & Keterangan \\
\cline { 2 - 3 } & Laba Kotor & Penjualan & & \\
\hline 2012 & 27.898 & 188.053 & $15 \%$ & $30 \%$ & Kurang Sehat \\
\hline 2013 & 27.523 & 193.880 & $14 \%$ & $30 \%$ & Kurang Sehat \\
\hline 2014 & 27.352 & 201.701 & $13 \%$ & $30 \%$ & Kurang Sehat \\
\hline 2015 & 19.630 & 184.196 & $10 \%$ & $30 \%$ & Kurang Sehat \\
\hline 2016 & 22.253 & 181.084 & $12 \%$ & $30 \%$ & Kurang Sehat \\
\hline
\end{tabular}

Sumber : Data yang diolah

Berdasarkan hasil perhitungan Gross Profit Margin (GPM) perusahaan PT Astra International Tbk. Pada tahun 2012 yaitu 15\% pada tahun 2013 sampai 2015 mengalami penurunan yaitu pada tahun 2013 turun 1\% menjadi 14\%, 2014 turun 1\% menjadi $13 \%$ dan pada tahun 2015 turun $3 \%$ menjadi 10\%, di tahun 2016 perusahaan mengalami kenaikan sebesar $2 \%$ yaitu menjadi $12 \%$. Maka dapat disimpulkan bahwa dari tahun 2012 sampai dengan 2016 Gross Profit Margin (GPM) PT.Astra 
International.Tbk di lihat dari standar industri kurang dari $30 \%$ di nyatakan Kurang sehat selama 5 Tahun Berturut-turut.

b. Return on Equity (ROE)

Return on Equity merupakan perbandingan antara laba bersih setelah pajak dengan total equity. suatu pengukuran dari penghasilan (income) yang tersedia bagi para opemilik perusahaan (baik pemegang saham biasa maupun pemegang saham preferen) atas modal yang mereka investasikan didalam perusahaan.

$$
\begin{aligned}
& \text { Return on Equity pada tahun } 2012=\frac{22.742}{89.814} \times 100 \%=25 \% \\
& \text { Return on Equity pada tahun } 2013=\frac{22.297}{106.188} \times 100 \%=21 \% \\
& \text { Return on Equity pada tahun } 2014=\frac{22.125}{120.324} \times 100 \%=18 \% \\
& \text { Return on Equity pada tahun } 2015=\frac{15.613}{126.553} \times 100 \%=12 \% \\
& \text { Return on Equity pada tahun } 2016=\frac{18.302}{139.906} \times 100 \%=13 \%
\end{aligned}
$$

Tabel 4.2

\section{Laporan Laba Bersih dan Modal PT. Astra International.Tbk Periode (2012-2016) (Dalam Miliaran Rupiah)}

\begin{tabular}{|c|c|c|c|c|c|}
\hline \multirow{2}{*}{ Tahun } & \multicolumn{2}{|c|}{ ROE } & Hasil & Standar & Keterangan \\
\cline { 2 - 5 } & Laba Bersih & Modal & ROE & $\begin{array}{l}\text { Industri } \\
\text { Ind }\end{array}$ & \\
\hline 2012 & 22.742 & 89.814 & $25 \%$ & $40 \%$ & Kurang Sehat \\
\hline 2013 & 22.297 & 106.188 & $21 \%$ & $40 \%$ & Kurang Sehat \\
\hline 2014 & 22.125 & 120.324 & $18 \%$ & $40 \%$ & Kurang Sehat \\
\hline 2015 & 15.613 & 126.533 & $12 \%$ & $40 \%$ & Kurang Sehat \\
\hline 2016 & 18.302 & 139.906 & $13 \%$ & $40 \%$ & Kurang Sehat \\
\hline
\end{tabular}

Sumber : Data yang diolah

Berdasarkan hasil perhitungan Return on Equity (ROE) perusahaan PT Astra International Tbk. Pada tahun 2012 yaitu 25\% pada tahun 2013 sampai 2015 menagalami penurunan yaitu pada tahun 2013 turun 4\% menjadi $21 \%$, 2014 turun 3\% menjadi $18 \%$ dan pada tahun 2015 turun $6 \%$ menjadi $12 \%$, di tahun 2016 perusahaan mengalami kenaikan sebesar $1 \%$ yaitu menjadi $13 \%$ Maka dapat disimpulkan bahwa dari tahun 2012 sampai dengan 2016 Return on Equity (ROE) PT.Astra International.Tbk di lihat dari standar industri kurang dari $40 \%$ di nyatakan Kurang sehat selama 5 Tahun Berturut-turut.

\section{Rasio Likuiditas}

Rasio Likuiditas adalah kemampuan untuk memenuhi kebutuhan dana (cash flow) dengan segera dan dengan biaya yang sesuai. berhubungan dengan masalah kemampuan suatu perusahaan untuk memenuhi kewajiban finansialnya yang segera harus dipenuhi jumlah alat-alat pembayaran (alat likuid) yang dimiliki oleh suatu perusahaan pada suatu saat merupakan kekuatan membayar dari perusahaan yang bersangkutan yang jatuh jangka tempo.

a. Rasio Lancar (Current Ratio)

Rasio Lancar (Current Ratio) biasanya digunakan sebagai alat untuk mengukur keadaan likuiditas suatu perusahaan dan juga merupakan petunjuk untuk dapat mengetahui dan menduga sampai dimanakah perusahaan tersebut memberikan kredit berjangka pendek dapat memberikan rasa aman. 
Current Ratio pada tahun $2012=\frac{75.799}{54.178} \times 100 \%=140 \%$

Current Ratio pada tahun $2013=\frac{88.352}{71.139} \times 100 \%=120 \%$

Current Ratio pada tahun $2014=\frac{97.241}{73.523} \times 100 \%=130 \%$

Current Ratio pada tahun $2015=\frac{105.161}{76.242} \times 100 \%=140 \%$

Current Ratio pada tahun $2016=\frac{110.403}{89.079} \times 100 \%=120 \%$

Tabel 4.3

Laporan Aktiva Lancar dan Kewajiban Lancar PT. Astra International.Tbk

Periode (2012-2016)

(Dalam Miliaran Rupiah)

\begin{tabular}{|c|c|c|c|c|c|}
\hline \multirow{2}{*}{ Tahun } & \multicolumn{2}{|c|}{$\mathrm{CR}$} & \multirow{2}{*}{$\begin{array}{c}\text { Hasil } \\
\text { CR }\end{array}$} & \multirow{2}{*}{$\begin{array}{l}\text { Standar } \\
\text { Industri }\end{array}$} & \multirow{2}{*}{ Keterangan } \\
\hline & Aktiva Lancar & Kewajiban Lancar & & & \\
\hline 2012 & 75.799 & 54.178 & $140 \%$ & $200 \%$ & Kurang Sehat \\
\hline 2013 & 88.352 & 71.139 & $120 \%$ & $200 \%$ & Kurang Sehat \\
\hline 2014 & 97.241 & 73.523 & $130 \%$ & $200 \%$ & Kurang Sehat \\
\hline 2015 & 105.161 & 76.242 & $140 \%$ & $200 \%$ & Kurang Sehat \\
\hline 2016 & 110.403 & 89.079 & $120 \%$ & $200 \%$ & Kurang Sehat \\
\hline
\end{tabular}

Sumber : Data yang diolah

Pada tahun 2012 Current Ratio pada PT Astra International Tbk sebesar 140\%. Maka setiap Rp. 1 utang lancar dijamin oleh Rp. 1,4 aktiva lancar.

Pada tahun 2013 Current Ratio pada PT Astra International Tbk sebesar 120\% . Maka setiap Rp. 1 utang lancar dijamin oleh Rp. 1,2 aktiva lancar.

Pada tahun 2014 Current Ratio pada PT Astra International Tbk sebesar 130\% . Maka setiap Rp. 1 utang lancar dijamin oleh Rp. 1,3 aktiva lancar.

Pada tahun 2015 Current Ratio pada PT Astra International Tbk sebesar 140\%. Maka setiap Rp. 1 utang lancar dijamin oleh Rp. 1,4 aktiva lancar.

Pada tahun 2016 Current Ratio pada PT Astra International Tbk sebesar 120\%. Maka setiap Rp. 1 utang lancar dijamin oleh Rp. 1,2 aktiva lancar.

Dan Selama 5 Tahun Berturut-turut PT. Astra International.Tbk Current Ratio dinyatakan kurang sehat karena dibawah standar industri $200 \%$.

b. Rasio Cepat (Quick Ratio)

Rasio Cepat (Quick Ratio) rasio ini disebut juga sebagai acid test ratio yaitu perbandingan antara aktiva lancar dikurangi persediaan dengan utang lancar rasio ini merupakan ukuran kemampuan perusahaan dalam memenuhi kewajibannya dengan tidak memperhitungkan persediaan. Quick ratio merupakan rasio antar jumlah aset lancar di luar persediaan dan biaya dibayar dimuka dengan liabilitas jangka pendek.

Quick Ratio pada tahun $2012=\frac{75.799-15.285}{54.178} \times 100 \%=110 \%$

Quick Ratio pada tahun $2013=\frac{88.352-14.433}{71.139} \times 100 \%=103 \%$

Quick Ratio pada tahun $2014=\frac{97.241-16.986}{73.523} \times 100 \%=109 \%$

Quick Ratio pada tahun $2015=\frac{105.161-18.337}{76.242} \times 100 \%=113 \%$

Quick Ratio pada tahun 2016= $\frac{110.403-17.771}{89.079} \times 100 \%=104 \%$ 
Tabel 4.4

Laporan Aktiva Lancar ,Kewajiban Lancar dan Persediaan

PT. Astra International.Tbk

Periode (2012-2016)

(Dalam Miliaran Rupiah)

\begin{tabular}{|c|c|c|c|c|c|c|}
\hline \multirow[b]{2}{*}{ Tahun } & \multicolumn{3}{|c|}{ QR } & \multirow[b]{2}{*}{ Hasil QR } & \multirow{2}{*}{$\begin{array}{l}\text { Standar } \\
\text { Industri }\end{array}$} & \multirow[b]{2}{*}{ Keterangan } \\
\hline & $\begin{array}{l}\text { Aktiva } \\
\text { Lancar }\end{array}$ & $\begin{array}{c}\text { Kewajiban } \\
\text { Lancar }\end{array}$ & Persediaan & & & \\
\hline 2012 & 75.799 & 54.178 & 15.285 & $110 \%$ & $150 \%$ & Kurang Sehat \\
\hline 2013 & 88.352 & 71.139 & 14.433 & $103 \%$ & $150 \%$ & Kurang Sehat \\
\hline 2014 & 97.241 & 73.523 & 16.986 & $109 \%$ & $150 \%$ & Kurang Sehat \\
\hline 2015 & 105.161 & 76.242 & 18.337 & $113 \%$ & $150 \%$ & Kurang Sehat \\
\hline 2016 & 110.403 & 89.079 & 17.771 & $104 \%$ & $150 \%$ & Kurang Sehat \\
\hline
\end{tabular}

Sumber : Data yang diolah

Pada tahun 2012 Quick Ratio pada PT Astra International Tbk sebesar 110\%. Maka setiap Rp. 1 utang lancar dijamin oleh Rp. 1,10 aktiva lancar

Pada tahun 2013 Quick Ratio pada PT Astra International Tbk sebesar 103\%. Maka setiap Rp. 1 utang lancar dijamin oleh Rp. 1,03 aktiva lancar

Pada tahun 2014 Quick Ratio pada PT Astra International Tbk sebesar 109\%. Maka setiap Rp. 1 utang lancar dijamin oleh Rp. 1,09 aktiva lancar

Pada tahun 2015 Quick Ratio pada PT Astra International Tbk sebesar 113\%. Maka setiap Rp. 1 utang lancar dijamin oleh Rp. 1,13 aktiva lancar

Pada tahun 2016 Quick Ratio pada PT Astra International Tbk sebesar 104\%. Maka setiap Rp. 1 utang lancar dijamin oleh Rp. 1,04 aktiva lancar

Dan Selama 5 Tahun Berturut-turut PT. Astra International.Tbk Quick Ratio dinyatakan Kurang sehat karena dibawah standar industri $150 \%$.

\section{d) Hasil Pembahasan}

Maka berdasarkan pengukuran dengan mengunakan Rasio Profitabilitas dan Rasio Likuiditas dari hasil laporan keuangan selama 5 (lima) tahun/periode yang di mulai dari tahun 2012 sampai dengan tahun 2016, maka dapat diperoleh hasil dari nilai rasio tersebut dalam gambar table sebagai berikut :

Tabel 4.5

Perhitungan Rasio Profitabilitas PT. Astra International.Tbk Periode (2012-2016)

\begin{tabular}{|c|c|c|c|c|c|c|c|}
\hline Keterangan & 2012 & 2013 & 2014 & 2015 & 2016 & $\begin{array}{c}\text { Standar } \\
\text { Industri }\end{array}$ & Kesimpulan \\
\hline GPM & $15 \%$ & $14 \%$ & $13 \%$ & $10 \%$ & $12 \%$ & $30 \%$ & Kurang Sehat \\
\hline ROE & $25 \%$ & $21 \%$ & $18 \%$ & $13 \%$ & $14 \%$ & $40 \%$ & Kurang Sehat \\
\hline
\end{tabular}


Pada tahun 2012 sampai dengan tahun 2016 Gross Profit Margin (GPM) PT.Astra International Tbk mengalami kenaikan dan penurunan,yaitu pada tahun 2012 sebesar 15\% pada tahun 2013 sampai dengan 2014 mengalami penurunan sebesar $1 \%$ yaitu pada tahun 2013 sebesar 14\% sedangkan pada tahun 2014 sebesar $13 \%$, pada tahun 2015 mengalami penurunan kembali sebesar 3\% yaitu menjadi sebsar $10 \%$ dan pada tahun berikut nya yaitu tahun 2016 mengalami kenaikan kembali sebesar 2\% yaitu menjadi 12\%. Maka Gross Profit Margin (GPM) dari tahun 2012 sampai dengan 2016 masih dikatakan kurang sehat bila dilihat dari standar industri itu sendiri yang sebesar $30 \%$.

Pada tahun 2012 sampai dengan tahun 2016 Return on Equity (ROE) PT.Astra International Tbk mengalami kenaikan dan penurunan,yaitu pada tahun 2012 sebesar $25 \%$ pada tahun 2013 sampai dengan 2015 terus menerus mengalami penurunan,pada tahun 2013 mengalami penurunan sebesar 4\% yaitu sebesar $21 \%$, pada tahun 2014 mengalami penurunan sebesar 3\% menjadi 18\%,dan pada tahun 2015 mengalami penurunan kembali sebesar $5 \%$ yaitu menjadi $13 \%$ dan pada tahun berikut nya yaitu tahun 2016 mengalami kenaikan kembali sebesar 1\% yaitu menjadi 14\%. Return on Equity (ROE) dari tahun 2012 sampai dengan 2016 masih dikatakan kurang sehat bila dilihat dari standar industri itu sendiri yang sebesar $40 \%$.

Tabel 4.6

Perhitungan Rasio Likuiditas PT. Astra International.Tbk Periode (2012-2016)

\begin{tabular}{|c|c|c|c|c|c|c|c|}
\hline Keterangan & 2012 & 2013 & 2014 & 2015 & 2016 & $\begin{array}{c}\text { Standar } \\
\text { Industri }\end{array}$ & Kesimpulan \\
\hline CR & $140 \%$ & $120 \%$ & $130 \%$ & $140 \%$ & $120 \%$ & $200 \%$ & Kurang Sehat \\
\hline QR & $110 \%$ & $103 \%$ & $109 \%$ & $113 \%$ & $104 \%$ & $150 \%$ & Kurang Sehat \\
\hline
\end{tabular}

Sumber : Data yang diolah

Pada tahun 2012 sampai dengan 2016 Current Ratio (CR) PT.Astra International.Tbk mengalami kenaikan dan penurunan, yaitu pada tahun 2012 sebesar $140 \%$,pada tahun 2013 mengalami penurunan sebesar 20\% menjadi 120\%,pada tahun 2014 sampai dengan 2015 mengalami kenaikan, ditahun 2014 kenaikan sebesar $10 \%$ menjadi $140 \%$, pada tahun 2015 mengalami kenaikan kembali sebesar $10 \%$ menjadi $140 \%$,dan pada tahun 2016 perusahaan mengalami penurunan sebesar $20 \%$ menjadi $120 \%$, maka Current Ratio (CR) dinyatakan kurang sehat dilihat dari standar industri itu sendiri yang sebesar $200 \%$.

Pada tahun 2012 sampai dengan 2016 Quick Ratio (QR) PT.Astra International.Tbk mengalami kenaikan dan penurunan,yaitu pada tahun 2012 sebesar $110 \%$, pada tahun 2013 mengalami penurunan sebsar 7\% menjadi 103\%,pada tahun 2014 sampai dengan 2015 mengalami kenaikan yaitu pada tahun 2014 mengalami kenaikan sebesar $6 \%$ menjadi 109\%, sedangkan pada tahun 2015 mengalami kenaikan kembali sebesar $4 \%$ menjadi $113 \%$ dan pada tahun 2016 mengalami penurunan kembali sebesar 9\% menjadi 104\%, maka Quick Ratio (QR) dinyatakan kurang sehat dilihat dari standar industri itu sendiri yang sebesar $150 \%$.

Kinerja Keuangan pada PT.Astra International.Tbk memperoleh rata-rata nilai dari Profitabilitas dengan menggunakan Gross Profit Margin (GPM) yang dihasilkan selama 5 (lima) tahun menunjukan angka $12,8 \%$ dan dengan menggunakan Return on Equity 
(ROE) selama 5 (lima) tahun menunjukan angka 17,8\%. Hal ini menunjukan Kinerja Keuangan perusahaan dari segi Profitabilitas dinyatakan kurang sehat. Kemudian dari segi Likuiditas dengan menggunakan Current Ratio (CR) selama 5 (lima) tahun menunjukan angka 130\% dan dengan menggunakan Quick Ratio (QR) selama 5 (lima) tahun menunjukan angka 107,8\%. Hal ini menunjukan Kinerja Keuangan perusahaan dari segi Likuiditas dinyatakan kurang sehat.

\section{e) Kesimpulan}

Berdasarkan paparan data dan pembahasan hasil penelitian, maka secara umum dapat disimpulkan beberapa hal yaitu :

1. Rasio Profitabilitas

Berdasarkan perhitungan dengan alat analisis Rasio Profitabilitas pada PT.Astra International.Tbk menggunakan alat ukur Gross Profit Margin (GPM) memperoleh hasil.Pada tahun 2012 sebesar 15\% pada tahun 2013 sampai dengan 2014 mengalami penurunan,pada tahun 2013 menjadi sebesar $14 \%$ sedangkan pada tahun 2014 menjadi sebesar 13\%, pada tahun 2015 mengalami penurunan kembali yaitu menjadi sebesar 10\% dan pada tahun berikut nya yaitu tahun 2016 mengalami kenaikan kembali yaitu menjadi sebesar 12\%. Maka Gross Profit Margin (GPM) dari tahun 2012 sampai dengan 2016 masih dikatakan kurang sehat bila dilihat dari standar industri itu sendiri yang sebesar 30\%. Seadangkan berdasarkan hasil perhitungan yang menggunakan alat ukur Return on Equity (ROE) memperoleh hasil Pada tahun 2012 sampai dengan tahun 2016 PT.Astra International.Tbk mengalami kenaikan dan penurunan,yaitu pada tahun 2012 sebesar 25\% pada tahun 2013 sampai dengan 2015 terus menerus mengalami penurunan,pada tahun 2013 mengalami penurunan menjadi sebesar $21 \%$, pada tahun 2014 mengalami penurunan menjadi sebesar 18\%,dan pada tahun 2015 mengalami penurunan kembali menjadi sebesar $12 \%$ dan pada tahun berikut nya yaitu tahun 2016 mengalami kenaikan kembali menjadi sebesar 13\%. Return on Equity (ROE) dari tahun 2012 sampai dengan 2016 masih dikatakan kurang sehat bila dilihat dari standar industri itu sendiri yang sebesar $40 \%$.

2. Rasio Likuiditas

Berdasarkan hasil pengukuran yang dilakukan dengan alat analisis Rasio Likuiditas pada PT.Astra international.Tbk yang diukur dengan Current Ratio (CR) mengalami kenaikan dan penurunan, yaitu pada tahun 2012 sebesar $140 \%$,pada tahun 2013 mengalami penurunan menjadi sebesar 120\%,pada tahun 2014 sampai dengan 2015 mengalami kenaikan, ditahun 2014 kenaikan menjadi sebesar $140 \%$, pada tahun 2015 mengalami kenaikan kembali menjadi sebesar 140\%,dan pada tahun 2016 perusahaan mengalami penurunan menjadi sebsar 120\%, maka Current Ratio (CR) dinyatakan kurang sehat dilihat dari standar industri itu sendiri yang sebesar $200 \%$. Sedangkan hasil pengukuran yang dilakukan dengan alat ukur Quick Ratio (QR) mengalami kenaikan dan penurunan,yaitu pada tahun 2012 sebesar $110 \%$, pada tahun 2013 mengalami penurunan menjadi sebesar 103\%,pada tahun 2014 sampai dengan 2015 mengalami kenaikan yaitu pada tahun 2014 mengalami kenaikan menjadi sebesar 109\%, sedangkan pada tahun 2015 mengalami kenaikan kembali menjadi sebesar 113\% dan pada tahun 2016 mengalami penurunan kembali menjadi sebesar 104\%, maka Quick Ratio (QR) dinyatakan kurang sehat dilihat dari standar industri itu sendiri yang sebesar $150 \%$.

3. Kinerja Keuangan dari Segi Rasio Profitabilitas dan Rasio Likuiditas

Kinerja Keuangan pada PT.Astra Intrernational.Tbk dilihat dari segi Rasio Profitabilitas dan Rasio Likuiditas dari hasil perhitungan laporan keuangan selama 5 (lima) tahun dari tahun 2012 sampai dengan tahun 2016 memperoleh rata-rata nilai dari Profitabilitas dengan menggunakan Gross Profit Margin (GPM) yang dihasilkan selama 5 (lima) tahun menunjukan angka 12,8\% dan dengan menggunakan Return on 
Equity (ROE) selama 5 (lima) tahun menunjukan angka 17,8\%. Hal ini menunjukan Kinerja Keuangan perusahaan dari segi Profitabilitas dinyatakan kurang sehat. Kemudian dari segi Likuiditas dengan menggunakan Current Ratio (CR) selama 5 (lima) tahun menunjukan angka 130\% dan dengan menggunakan Quick Ratio (QR) selama 5 (lima) tahun menunjukan angka 107,8\%. Hal ini menunjukan Kinerja Keuangan perusahaan dari segi Likuiditas dinyatakan kurang sehat.

\section{Daftar Pustaka}

Alma,Buchari, “Pengantar Bisnis”, Edisi Revisi, Cetakan 16,CV.Alfabeta, Bandung,2013.

Anoraga,Pandji, "Manajemen Bisnis", Cetakan Kedua, PT.Rineka Cipta, Jateng,2000

Brigham,E.F dan Houston J.f, "Dasar-Dasar Manajemen Keuangan", Edisi 11, Salemba Empat,Jakarta,2010.

Carl S,Warren dkk “Pengantar Akuntansi”, Edisi 21,Salemba Empat, Jakarta,2014.

Darsono, "Manajemen Keuangan Pendekatan Praktis Kajian Pengambilan Keputusan Bisnis Berbasis Analisis Keuangan",Nusantara Consulting,2006.

Dunia,Firdaus,A "Pengantar Akuntansi" Edisi 4, Fakultas Ekonomi Universitas Indonesia,Jakarta,2013.

Fahmi,Irham, "Pengantar Manajemen Keuangan", Penerbit Ekonisia, Yogyakarta,2011

Handoko,T.Hani, "Manajemen", Edisi Kedua,Cetakan Kedua Puluh Satu, Penerbit : BPEE, Yogyakarta,2011

Hasan,Iqbal, "Pokok-pokok Materi Metodologi Penelitian dan Aplikasinya", Cetakan 1,Galia Indonesia,Jakarta,2002.

Husnan,Suad dan Punjiastuti Enny, "Dasar-Dasar Manajemen Keuangan”, Edisi 3, UPP AMP YKPN, Yogyakarta,2006.

Juhandi,Nendi, “Manajemen Keuangan Lanjutan”,Pelangi Nusantara,Jakarta,2007.

Kadim, A., \& Sunardi, N. (2019, May). Eviews Analysis; Determinan Tourism, Restaurant and Hotel Company's Soundness and Performance. In Proceeding Interuniversity Forum for Strengthening Academic Competency (Vol. 1, No. 1, pp. 332-340).

Kasmir, “Analisis Laporan Keuangan”,PT.Raja Grafindo Persada,Jakarta,2008.

Kasmir, "Analisis Manajemen Keuangan",Kencana,Jakrta,2010

Mulyadi, "Akutansi Manajemen", UPP STIE YKPN, Yogyakarta, 2010

Munawir,S “Analisis Laporan Keuangan”,Edisi 4,Liberty,Yogyakarta,2010

Munawir,S “Analisis Laporan Keuangan”,Penerbit Liberty, Yogyakarta,2004

Rangkuti,Frenddy "Measuring Costumer Satisfaction Teknik Mengukur Dan Strategi Meningkatkan Kepuasan Pelanggan", PT. Gramedia Pustaka Utama, Jakarta,2009

Riyanto,Bambang "Dasar-Dasar Pembelajaran Perusahaan".Edisi Kemepat BPFE, Yogyakarta.2010.

Sawir,Agnes "Analisis Kinerja Keuangandan Perencanaan Keuangan Perusahaan", PT.Gramedia Pustaka Utama,Jakarta,2009

Solihin,Ismail “Pengantar Manajemen”, Erlangga, Jakarta,2009

Steephen P. Robbins dan Mary Coulter, "Manajemen", Edisi Kesepuluh, Jilid 1, Erlangga,2010.

Sugiyono, "Metode Penelitian Pendidikan Pendekatan Kuantatif,Kualitatif dan R\&D"Alfabeta,Bandung,2010.

Sugiyono, "Metode Penelitian Pendidikan Pendekatan Kuantatif,Kualitatif dan R\&D" Alfabeta,Bandung,2012.

Sugiyono, "Metode Penelitian Pendidikan Pendekatan Kuantatif,Kualitatif dan R\&D" Alfabeta,Bandung,2014.

Sunardi, N. (2018). Analisis Du Pont System Dengan Time Series Approach (Tsa) Dan Cross Sectional Approach (Csa) Dalam Penilaian Kinerja Keuangan Perusahaan (Studi Pada Industri Konstruksi (BUMN) di Indonesia Yang Listing di BEl Tahun 2013-2017). Jurnal SEKURITAS (Saham, Ekonomi, Keuangan dan Investasi), 1(4). 
Sunardi, N. (2019). Determinan Intelectual Capital dengan Pendekatan iB-VAIC TM Terhadap Efisiensi Biaya Implikasinya Pada Profitabilitas Perbankan Syariah di Indonesia. JIMF (Jurnal IImiah Manajemen Forkamma), 1(1).

Sunardi, N., \& Sasmita, A. S. (2019). Pengaruh Likuiditas, Leverage Dan Growth Terhadap Kinerja Industri Makanan Dan Minuman Yang Tercatat Di Indonesia Stock Exchange Selama Periode Tahun 2011-2015. Jurnal Sekuritas (Saham, Ekonomi, Keuangan dan Investasi), 2(2), 81-97.

Sunardi, N., Hamid, A. A., Lativa, A. K., \& Tulus, N. (2018). Determinant Of Cost Efficiency And It's Implications For Companies Performance Incorporated In The Lq. 45 Index Listing In Idx For The Period of 2011-2016. International Journal of Applied Business and Economic Research, 16(1).

Sutrisno, "Manajemen Keuangan Teori, Konsep dan Aplikasi" Penerbit Ekonisia, Yogyakarta,2009.

Sutrisno, "Manajemen Keuangan Teori, Konsep dan Aplikasi" Penerbit Ekonisia, Yogyakarta,2012

Suyanto,Danang “Dasar-Dasar Manajemen”, CAPS,Yogyakarta,2013.

Syamsudin,Lukman "Manajemen Keuangan Perusahaan”, PT.Raja Grafindo Persada,2007 Terry.R.George "Asas-Asas Manajemen", Penerbit Alumni Bandung,Bandung, 1986

Terry.R.George dan Rue,Leslie "Dasar-Dasar Manajemen”, Penerbit Bumi Aksara, Jakarta, 2010

Van Horne,James C dan John M,Wachowicz,Jr, "Prinsip-Prinsip Manajemen Keuangan" ,Buku Satu,Edisi 12, Penerbit Salemba Empat,Jakarta, 2005

Weston,J Fred Copeland,E,Thomas, "Manajemen Keuangan”, Edisi Sembilan, Bina Rupa Aksara,Jakarta,2009

www.idx.co.id

http ://www.astra.co.id/ 